\title{
Energetic Values and Inclusion Levels of the Dry Residue of Cassava in Broiler Diet
}

שAuthor(s)
$\begin{array}{ll}\text { Trautenmüller H' } & \text { (D) https://orcid.org/0000-0002-9546-892X } \\ \text { Broch J' } & \text { (D) https://orcid.org/0000-0002-0799-9473 } \\ \text { Pires Filho IC' } & \text { (D) https://orcid.org/0000-0002-8063-7946 } \\ \text { Silva IM' } & \text { (D) https://orcid.org/0000-0002-0165-8942 } \\ \text { Frank R' } & \text { (D) https://orcid.org/0000-0003-0745-4737 } \\ \text { Schöne RA' } & \text { (iD https://orcid.org/0000-0001-5235-2997 } \\ \text { Carvalho PLO' } & \text { (D) https://orcid.org/0000-0001-9273-3209 } \\ \text { Eyng C' } & \text { (D) https://orcid.org/0000-0001-8839-3758 } \\ \text { Nunes RV' } & \text { (iD https://orcid.org/0000-0002-9376-2826 }\end{array}$

Western Paraná State University (UNIOESTE) Marechal Cândido Rondon / Paraná - Brazil.

\section{-Mail Address}

Corresponding author e-mail address Jomara Broch

Universidade Estadual do Oeste do Paraná - Campus de Marechal Cândido Rondon - Centro de Ciências Agrárias - Rua Pernambuco, 1777 - Caixa Postal: 91 - CEP 85960-000 - Marechal Cândido Rondon PR - Brasil.

Phone: +55 45991086235

Email: brochjomara@yahoo.com.br

\section{-Keywords}

Poultry farming, co-product, cassava, intestinal morphometry.

\section{ABSTRACT}

The objective of this study was to evaluate the energetic values of dry residue of cassava (DRC) and the effects of its inclusion in broiler diets on performance, intestinal morphometry, protein and fat deposition rate, and carcass and cut yields. In experiment I, two metabolism trials were carried out from 11-21 and from 31-41 days of age. The birds were distributed in a completely randomized design and DRC was included at levels of 10,20, 30 and $40 \%$ in the basal diet. In experiment II, 980 male chicks were distributed in a completely randomized design with seven treatments $(0 ; 2 ; 4 ; 6 ; 8 ; 10 ; 12 \%$ DRC) and seven replicates. DRC levels did not influence $(p>0.05)$ the energetic values. From days 1-7, weight gain (WG) had a linear adjustment, and the inclusion of up to $6 \%$ of DRC from d $1-7$, and the feed conversion ratio (FCR) had a tendency $(p=0.060)$ with quadratic effect $(p=0.001)$, and the worst FCR was observed with the inclusion of $5.81 \%$ of DRC. From d $1-21$ of age, the WG decreased linearly, with the increasing of DRC while the FCR increased linearly. Breast yield decreased linearly with increasing levels of DRC inclusion. The addition of the residue reduced the protein deposition rate (PDR) and did not alter the (fat deposition rate) FDR. The metabolizable energy of DRC was $1534 \mathrm{kcal} \mathrm{kg}^{-1}$ (11-21 d), 1746 $\mathrm{kcal} \mathrm{kg}^{-1}(\mathrm{~d} 31-42)$ and can be included up to $6 \%$ until $\mathrm{d} 42$ in the broiler's diet without harming the performance.

\section{INTRODUCTION}

Cassava (Manihot esculenta Crantz) is an energetic feedstuff important in poultry diets, which has the potential to replace maize in diets, allowing a reduction in feed costs. However, the use of its products can be limited by its high fiber content and the presence of anti-nutritional factors such as hydrocyanic acid (HCN; Morgan \& Choct, 2016).

Cassava has a high concentration of non-starch polysaccharides (NSPs), which have high hydration capacity and are responsible for increasing the viscosity of gastrointestinal contents and decreasing access of endogenous enzymes, reducing the intensity of contact between nutrients and enzymes, and affecting negatively nutrient digestibility and energy utilization (Brito et al., 2008; Nikan et al., 2016). Birds do not have endogenous enzymes capable of hydrolyzing NSP bonds, so they perform fermentation of the fibrous material in the cecum, producing short-chain fatty acids (Bindelle et al., 2008).

Processing cassava by heating with water and subsequent drying may cause gelatinization and retrogradation of starch that occurs mainly in the amylose portion, due to the nature of its structure that facilitates the formation of hydrogen bridges in its granules (Sajilata et al., 2006). Retrograded starch, also called resistant starch, 
Trautenmüller H, Broch J, Pires Filho IC, Silva IM, Frank R, Schöne RA, Carvalho PLO, Eyng C, Nunes RV
Energetic Values and Inclusion Levels of the Dry Residue of Cassava in Broiler Diet is the undigested fraction from the upper portion of the small intestine that reaches the large intestine intact, where it undergoes fermentation through the intestinal microbiota to form short-chain fatty acids; its effect may be compared to fiber feed (Walter et al., 2005).

Dry residue of cassava (DRC) has an average $9.52 \%$ humidity, $63.85 \%$ starch, $14.88 \%$ crude fiber (Abrahão et al., 2006), $3519 \mathrm{kcal} \mathrm{kg}^{-1}$ gross energy, $0.98 \%$ crude protein, $27.0 \%$ neutral detergent fiber and 19.5\% acid detergent fiber (Broch et al., 2017). According to Carrijo et al. (2010), the inclusion of up to $45 \%$ of cassava whole root meal can be administered to freerange chickens without affecting their performance. Up to $2 \%$ DRC can be used in Isa Label male broiler diets; values above this reduce feed intake and weight gain from 21 to 49 days of age (Picoli et al., 2014).

According to Broch et al. (2017), so long as it is associated with carbohydrases, up to $10 \%$, DRC can be used in broiler diet from 1 to 21 days of age without affecting performance, carcass and cut yields. Similarly, according to Silva et al. (2019), 10\% of DRC can be used in broiler diets from 21 to 42 days of age when associated with carbohydrase to maintain performance.

The objective of this study was to evaluate the energetic values of DRC and the effects of its inclusion in broiler diets on performance, intestinal morphometry, protein and fat deposition rate, and carcass and cut yields.

\section{MATERIAL AND METHODS}

The studies were carried out in the Poultry Sector of the Western Paraná State University, Campus Marechal Cândido Rondon - Paraná, Brazil. All experimental procedures were approved by the University ethical review committee (number 19/13).

The DRC was dried under the pressure of $9 \mathrm{~kg} \mathrm{~h}^{-1}$ for 15 to 20 minutes. Upon receipt of the DRC, a sample was subjected to analysis of the chemical composition of dry matter (DM) (method 934.01), mineral matter (method 938.08), crude protein (CP) (method 981.10), ether extract (EE) (method 920.85) according to the methodology described by AOAC (2000). Gross energy (GE) was determined in a calorimetric bomb (IKA C2000), and neutral detergent fiber (NDF) and acid detergent fiber (ADF) were determined according to Van Soest et al. (1991). Starch and crude fiber content were determined by the São Camilo Group Food and Water Laboratory (Maringá, PR).

\section{Experiment I}

A total of 250 male one-day-old Cobb 500 broiler chicks were used from 11 to 21 days of age in the first trial and a total of 125 male broiler chickens from 31 to 41 days of age in the second trial. The birds were distributed into a completely randomized design with five treatments and five replications per treatment, with ten birds per metabolic cage (experimental unit EU) in Trial I, and five birds per EU in Trial II.

For both experiments, DRC replaced 10, 20, 30 and $40 \%$ of the reference rations (Table 1); the experimental diets were in mash form, isonitrogenous and isocaloric, and formulated according to Rostagno et al. (2011). Throughout the trial period, the room temperature was maintained within the zone of thermal comfort and feed and water were offered ad libitum.

The experimental period for both trials was ten days: five days for adaptation to cages and diets and five days for total excreta collection. The excreta were collected every $12 \mathrm{~h}$ and stored in plastic bags at $-20{ }^{\circ} \mathrm{C}$. At the end of the experimental period, the excreta were quantified, homogenized, air-dried, and ground. Then the DM, nitrogen $(\mathrm{N})$, and crude energy (CE) contents were analyzed together with a sample of DRC (AOAC, 2000).

For the determination of apparent metabolizable energy (AME) and AME corrected by nitrogen balance $\left(\mathrm{AME}_{n}\right)$, the total excreta collection method was used, according to Sibbald and Slinger (1963). The apparent metabolizable coefficient (AMC) was calculated as a function of the metabolizable energy value by the $G E$ value. $A M E$ and $A M E_{n}$ values were determined according to the methodology of Lesson and Summers (2001).

\section{Experiment II}

A total of 980 male one-day-old Cobb Slow broiler chicks were distributed in a completely randomized design with seven treatments $(0,2.0,4.0,6.0,8.0$, 10.0, and $12.0 \%$ inclusion of DRC), with seven replications and 20 birds per EU. The birds were housed in a poultry house with a concrete floor lined with pine shavings litter, divided into pens $\left(1.96 \mathrm{~m}^{2}\right)$ equipped with tubular feeders and nipple drinkers. The feed was offered in mash form and water ad libitum throughout the experimental period. The lighting program used was following the recommendation of the lineage manual; the room temperature was maintained within the zone of thermal comfort, the cooling of the environment, and the renewal of the air was carried out by exhaust fans and evaporative plates. 
Trautenmüller H, Broch J, Pires Filho IC,

Silva IM, Frank R, Schöne RA,

Carvalho PLO, Eyng C, Nunes RV
Energetic Values and Inclusion Levels of the Dry Residue of Cassava in Broiler Diet

Table 1 - Composition and nutrient specifications of the experimental diets used for broilers from metabolism and performance trials.

\begin{tabular}{|c|c|c|c|c|c|c|c|c|c|}
\hline \multirow{3}{*}{$\begin{array}{l}\text { Ingredients }\left(\mathrm{g} \mathrm{kg}^{-1}\right) \\
\text { Dry residue of cassava }\end{array}$} & \multicolumn{2}{|c|}{ Experiment I } & \multicolumn{7}{|c|}{ Experiment II } \\
\hline & Starter & Grower & \multicolumn{7}{|c|}{ Pre starter $1-7 \mathrm{~d}$ of age } \\
\hline & 0.0 & 0.0 & 0.0 & 20.0 & 40.0 & 60.0 & 80.0 & 100.0 & 120.0 \\
\hline Corn grain & 567.8 & 662.7 & 543.9 & 518.0 & 492.4 & 466.5 & 440.4 & 414.3 & 388.3 \\
\hline Soybean meal $\left(450 \mathrm{~g} \mathrm{~kg}^{-1}\right)$ & 359.5 & 276.7 & 387.8 & 391.8 & 395.8 & 399.7 & 403.7 & 407.7 & 401.7 \\
\hline Soybean oil & 33.5 & 30.0 & 24.3 & 26.4 & 28.3 & 30.4 & 32.7 & 35.0 & 37.3 \\
\hline Dicalcium phosphate & 13.6 & 9.5 & 19.0 & 19.1 & 19.1 & 19.1 & 19.1 & 19.1 & 19.1 \\
\hline Limestone & 12.8 & 10.0 & 9.1 & 9.0 & 8.8 & 8.6 & 8.4 & 8.2 & 8.0 \\
\hline $\mathrm{NaCl}$ & 4.8 & 4.4 & 5.1 & 5.1 & 5.1 & 5.1 & 5.1 & 5.1 & 5.1 \\
\hline Premix $^{1}$ & 1.5 & 1.5 & 1.5 & 1.5 & 1.5 & 1.5 & 1.5 & 1.5 & 1.5 \\
\hline L-Lysine. $\mathrm{HCl}(78 \%)$ & 2.4 & 2.2 & 2.9 & 2.8 & 2.8 & 2.7 & 2.6 & 2.6 & 2.5 \\
\hline DL-Methionine (99\%) & 3.1 & 2.4 & 3.7 & 3.7 & 3.7 & 3.7 & 3.8 & 3.8 & 3.8 \\
\hline L-Treonine (98\%) & 0.8 & 0.5 & 1.2 & 1.2 & 1.2 & 1.2 & 1.2 & 1.2 & 1.2 \\
\hline Choline chloride (60\%) & 0.0 & 0.0 & 0.6 & 0.6 & 0.6 & 0.6 & 0.6 & 0.6 & 0.6 \\
\hline \multirow[t]{2}{*}{ Aditives $^{2}$} & 0.2 & 0.2 & 0.9 & 0.9 & 0.9 & 0.9 & 0.9 & 0.9 & 0.9 \\
\hline & \multicolumn{9}{|c|}{ Nutrient specification $\left(\mathrm{g} \mathrm{kg}^{-1}\right)$} \\
\hline Met. Em. (kcal kg-1) & 3052 & 3150 & 2960 & 2960 & 2960 & 2960 & 2960 & 2960 & 2960 \\
\hline Crude protein & 212 & 181.2 & 224 & 224 & 224 & 224 & 224 & 224 & 224 \\
\hline Calcium & 8.4 & 6.4 & 9.2 & 9.2 & 9.2 & 9.2 & 9.2 & 9.2 & 9.2 \\
\hline Av. $P$ & 4.0 & 3.0 & 4.7 & 4.7 & 4.7 & 4.7 & 4.7 & 4.7 & 4.7 \\
\hline Digestible Lysine & 12.2 & 10.1 & 13.2 & 13.2 & 13.2 & 13.2 & 13.2 & 13.2 & 13.2 \\
\hline Digestible Met+cys & 8.8 & 7.4 & 9.5 & 9.5 & 9.5 & 9.5 & 9.5 & 9.5 & 9.5 \\
\hline Digestible Threonine & 7.9 & 6.6 & 8.6 & 8.6 & 8.6 & 8.6 & 8.6 & 8.6 & 8.6 \\
\hline Chlorine & 3.4 & 3.2 & 3.5 & 3.5 & 3.5 & 3.5 & 3.5 & 3.5 & 3.5 \\
\hline Sodium & 2.1 & 2.0 & 2.2 & 2.2 & 2.2 & 2.2 & 2.2 & 2.2 & 2.2 \\
\hline Potassium & 8.2 & 7.0 & 8.7 & 8.7 & 8.7 & 8.7 & 8.7 & 8.7 & 8.7 \\
\hline
\end{tabular}

${ }^{1}$ Levels of guarantee per kilo of feed, vitamin (Lot BR0119Y025): Vit. A (min) 1350000 IU; Vit. D3 (min) 375000 IU; Vit. E (min) 3000 IU; Vit. K3 (min) 375 mg; Vit. B1 (min) 225 mg; Vit. B2 (min) 900 mg; Vit. B6 (min) 450 mg; Vit. B12 1800 mg; Pantothenic Acid (min) 1.8 g; Niacin (min) 3.75 g; Folic Acid (min) 120 mg; Selenium (min) 37.5 mg; Mineral (Lot BR0112B375): Cu (min) 3g, Fe (min) 15g, Mg (min) 300 mg, Zn (min) 15g. ${ }^{2}$ Antococcidian (Coxistac, $60 \mathrm{~g} \mathrm{ton}^{-1}$ ), Growth promoter (Enradin, $10 \mathrm{~g}$ ton ${ }^{-1}$ ), Antioxidant (BHT, $20 \mathrm{~g}$ ton ${ }^{-1}$ ).

The experimental diets, isoenergetic and isonutritive, were formulated to meet the nutritional requirements recommended by Rostagno et al. (2011) for pre-starter (1-7 d of age; Table 1), starter (8-21 d of age) and grower (22-42 d of age) phases (Table 2).

Birds and diets were weighed at 7, 21, and $42 \mathrm{~d}$ of age for feed intake (FI), weight gain (WG), and feed conversion ratio (FCR) evaluation. Mean individual bird weight and intake were corrected using the weight of dead birds, which was recorded daily, according to Sakomura and Rostagno (2016).

At $42 \mathrm{~d}$ of age, two birds per EU, $\pm 5 \%$ of the average weight per treatment, after six $h$ of fasting, were euthanized by electronarcosis followed by exsanguination, according to Normative Resolution №. 37 of February 15, 2018, of CONCEA, for the evaluation of carcass yield, cuts and meat quality.

The eviscerated carcass weight was compared (without feet, head, neck, and abdominal fat) with the weight of the pre-slaughter bird. Breast, leg, and wing yields were calculated using the weight of the eviscerated carcass. The percentage of abdominal fat was obtained from fat removed from the cloaca and around the gizzard. Also, the relative weight of the liver (\% of live weight) was determined.

For analysis of duodenal morphometry, the small intestine was removed by an incision in the ventrocaudal region, and cuts were taken to collect fragments in the approximately $5 \mathrm{~cm}$ ascending portion of this segment. The pieces, about $2 \mathrm{~cm}$ in length, were carefully collected, washed with distilled water and fixed in buffered formalin solution (10\%), then dehydrated in a series of increasingly concentrated alcohol solutions, diaphanized in xylene and embedded in paraffin (Luna, 1968). After semi-serial microtomy, $7-\mu \mathrm{m}$ sections were stained by the hematoxylin and eosin technique.

The histological sections were analyzed by an optical microscope, and ten villi and crypts were measured in different regions of the section. The villus height measurements were taken from the upper crypt base to the villus apex, and the crypt depth measurements were made between the villi from the lower plate to the upper crypt base.

To determine the protein and fat deposition rate in the carcass $\left(\mathrm{g} \mathrm{day}^{-1}\right)$, the methodology adapted from 
Trautenmüller H, Broch J, Pires Filho IC, Silva IM, Frank R, Schöne RA, Carvalho PLO, Eyng C, Nunes RV
Energetic Values and Inclusion Levels of the Dry Residue of Cassava in Broiler Diet

Table 2 - Composition and nutrient specifications of the experimental diets used for broilers from performance trial.

\begin{tabular}{|c|c|c|c|c|c|c|c|c|c|c|c|c|c|c|}
\hline & \multicolumn{14}{|c|}{ Experiment II } \\
\hline Ingredients $\left(\mathrm{g} \mathrm{kg}^{-1}\right)$ & \multicolumn{7}{|c|}{ Starter 8-21d of age } & \multicolumn{7}{|c|}{ Grower 22-42 d of age } \\
\hline Dry residue of cassava & 0.0 & 20.0 & 40.0 & 60.0 & 80.0 & 100.0 & 120.0 & 0.0 & 20.0 & 40.0 & 60.0 & 80.0 & 100.0 & 120.0 \\
\hline Corn grain & 565.1 & 539.4 & 513.4 & 487.4 & 461.8 & 435.4 & 409.3 & 616.2 & 589.7 & 562.8 & 535.8 & 508.9 & 482.0 & 455.1 \\
\hline Soybean meal $\left(450 \mathrm{~g} \mathrm{~kg}^{-1}\right)$ & 360.0 & 363.9 & 367.9 & 371.9 & 375.8 & 379.8 & 383.8 & 310.4 & 314.9 & 319.5 & 324.0 & 328.6 & 333.2 & 337.8 \\
\hline Soybean oil & 34.2 & 36.2 & 38.4 & 40.6 & 42.5 & 45.0 & 47.3 & 36.2 & 38.4 & 40.9 & 43.5 & 46.0 & 48.6 & 51.1 \\
\hline Dicalcium phosphate & 13.9 & 13.9 & 13.9 & 13.9 & 13.9 & 13.9 & 13.9 & 11.4 & 11.4 & 11.4 & 11.5 & 15.1 & 11.5 & 11.6 \\
\hline Limestone & 12.8 & 12.6 & 12.4 & 12.2 & 12.0 & 11.8 & 11.6 & 12.0 & 11.8 & 11.6 & 11.4 & 11.2 & 11.0 & 10.8 \\
\hline $\mathrm{NaCl}$ & 4.8 & 4.8 & 4.9 & 4.9 & 4.9 & 4.9 & 4.9 & 4.4 & 4.5 & 4.5 & 4.5 & 4.5 & 4.5 & 4.5 \\
\hline Premix ${ }^{1}$ & 1.5 & 1.5 & 1.5 & 1.5 & 1.5 & 1.5 & 1.5 & 1.5 & 1.5 & 1.5 & 1.5 & 1.5 & 1.5 & 1.5 \\
\hline L-Lysine.HCI (78\%) & 2.4 & 2.3 & 2.3 & 2.2 & 2.1 & 2.1 & 2.0 & 2.7 & 2.6 & 2.5 & 2.5 & 2.4 & 2.3 & 2.2 \\
\hline DL-Methionine (99\%) & 3.1 & 3.2 & 3.2 & 3.2 & 3.2 & 3.3 & 3.3 & 2.8 & 2.8 & 2.9 & 2.9 & 3.0 & 3.0 & 3.0 \\
\hline L-Threonine (98\%) & 0.8 & 0.8 & 0.8 & 0.8 & 0.8 & 0.9 & 0.9 & 0.9 & 0.9 & 0.9 & 0.9 & 0.9 & 0.9 & 0.9 \\
\hline Choline chloride (60\%) & 0.6 & 0.6 & 0.6 & 0.6 & 0.6 & 0.6 & 0.6 & 0.6 & 0.6 & 0.6 & 0.6 & 0.6 & 0.6 & 0.6 \\
\hline \multirow[t]{2}{*}{ Aditives $^{2}$} & 0.9 & 0.9 & 0.9 & 0.9 & 0.9 & 0.9 & 0.9 & 0.9 & 0.9 & 0.9 & 0.9 & 0.9 & 0.9 & 0.9 \\
\hline & \multicolumn{14}{|c|}{ Nutrient specification $\left(\mathrm{g} \mathrm{kg}^{-1}\right)$} \\
\hline Met. Em. $\left(\mathrm{kcal} \mathrm{kg}^{-1}\right)$ & 3050 & 3050 & 3050 & 3050 & 3050 & 3050 & 3050 & 3150 & 3150 & 3150 & 3150 & 3150 & 3150 & 3150 \\
\hline Crude protein & 212 & 212 & 212 & 212 & 212 & 212 & 212 & 198 & 198 & 198 & 198 & 198 & 198 & 198 \\
\hline Calcium & 8.4 & 8.4 & 8.4 & 8.4 & 8.4 & 8.4 & 8.4 & 7.6 & 7.6 & 7.6 & 7.6 & 7.6 & 7.6 & 7.6 \\
\hline Av. $P$ & 4.0 & 4.0 & 4.0 & 4.0 & 4.0 & 4.0 & 4.0 & 3.5 & 3.5 & 3.5 & 3.5 & 3.5 & 3.5 & 3.5 \\
\hline Digestible Lysine & 12.2 & 12.2 & 12.2 & 12.2 & 12.2 & 12.2 & 12.2 & 11.3 & 11.3 & 11.3 & 11.3 & 11.3 & 11.3 & 11.3 \\
\hline Digestible Met+cys & 8.8 & 8.8 & 8.8 & 8.8 & 8.8 & 8.8 & 8.8 & 8.3 & 8.3 & 8.3 & 8.3 & 8.3 & 8.3 & 8.3 \\
\hline Digestible Threonine & 7.9 & 7.9 & 7.9 & 7.9 & 7.9 & 7.9 & 7.9 & 7.4 & 7.4 & 7.4 & 7.4 & 7.4 & 7.4 & 7.4 \\
\hline Chlorine & 3.4 & 3.4 & 3.4 & 3.4 & 3.4 & 3.4 & 3.4 & 3.1 & 3.1 & 3.1 & 3.1 & 3.1 & 3.1 & 3.1 \\
\hline Sodium & 2.1 & 2.1 & 2.1 & 2.1 & 2.1 & 2.1 & 2.1 & 2.0 & 2.0 & 2.0 & 2.0 & 2.0 & 2.0 & 2.0 \\
\hline Potassium & 8.2 & 8.2 & 8.2 & 8.2 & 8.2 & 8.2 & 8.2 & 7.5 & 7.5 & 7.5 & 7.5 & 7.5 & 7.5 & 7.5 \\
\hline
\end{tabular}

${ }^{1}$ Levels of guarantee per kilo of feed, vitamin (Lot BR0119Y025): Vit. A (min) 1350000 IU; Vit. D3 (min) 375000 IU; Vit. E (min) 3000 IU; Vit. K3 (min) 375 mg; Vit. B1 (min) 225 mg; Vit. B2 (min) 900 mg; Vit. B6 (min) 450 mg; Vit. B12 1800 mg; Pantothenic Acid (min) 1.8 g; Niacin (min) 3.75 g; Folic Acid (min) 120 mg; Selenium (min) 37.5 mg; Mineral (Lot BR0112B375): Cu (min) 3g, Fe (min) 15g, Mg (min) 300 mg, Zn (min) 15g. ${ }^{2}$ Antococcidian (Coxistac, $60 \mathrm{~g} \mathrm{ton}^{-1}$ ), Growth promoter (Enradin, $10 \mathrm{~g}$ ton- ${ }^{-1}$, Antioxidant (BHT, $20 \mathrm{~g}$ ton ${ }^{-1}$ ).

Fraga et al. (2008) was used. At the beginning of the experimental period, a group of 20 broilers with average weight were slaughtered, weighed, plucked, and stored at $-20^{\circ} \mathrm{C}$. At 42 days of age, a bird within the EU average plucked weight was sacrificed by cervical dislocation. The carcass without feathers was ground in a meat grinder, pre-dried in a forced ventilation oven, ground in a ball mill and subjected to analysis of DM, EE and CP. Protein deposition rate (PDR) and fat deposition rate (FDR) were measured by comparing birds slaughtered at the end of the experimental period with a new group of chicks slaughtered in the housing.

The data were submitted to normality and homogeneity of variance evaluation and the outliers removed. Analysis of variance and subsequent polynomial regression was performed, excluding the positive control (PC) treatment. Also, Dunnett's test was performed at the $5 \%$ probability level to compare the PC treatment with the other treatments. All statistical analyses were performed using the PROC GLM procedure of the SAS University (2018) statistical software. The mathematical model used was:

$$
y_{i j}=\mu+t_{i}+e_{i j}
$$

Where: $\gamma \mathrm{ij}=$ observation, $\mu=$ overall mean, $\mathrm{ti}=$ effect of treatment, and eij = experimental random residual error.

\section{RESULTS}

DRC has a low EE $\left(3.1 \mathrm{~g} \mathrm{~kg}^{-1}\right)$ and CP $\left(11.2 \mathrm{~g} \mathrm{~kg}^{-1}\right)$ contents and high concentrations of crude fiber (CF) (135.7 $\mathrm{g} \mathrm{kg}^{-1}$ ) and ADF (208.2 $\mathrm{g} \mathrm{kg}^{-1}$; Table 3). The energetic values ( $A M E$ and $A M E_{n}$ ), as well as their respective metabolizable coefficients ( $A M C$ and $A M C_{n}$ ) were not influenced ( $p>0.05)$ by the DRC substitution levels for birds in the starter and finisher phases (Table 3).

Inclusion of up to $12 \%$ of DRC in broiler diets reduced the birds' WG (Table 4). WG showed a linear behavior in all phases of the growth, and birds fed an inclusion of up to $6 \%$ DRC from 1-7 $d$ and 1-21 $d$ of age showed the same WG compared with those that received the basal diet ( $0 \% D R C)$. Continued use of DRC from 1-42 $d$ of age impaired broilers' WG, and at this stage, only the inclusion of $2 \%$ provided the same gain as in birds fed the control treatment. Fl showed a difference $(p<0.01)$ by Dunnett's Test only in days $1-7$, 
Trautenmüller H, Broch J, Pires Filho IC,

Silva IM, Frank R, Schöne RA,

Carvalho PLO, Eyng C, Nunes RV
Energetic Values and Inclusion Levels of the Dry

Residue of Cassava in Broiler Diet

Table 3 - Chemical composition, energy values and metabolization coefficients of dry residue of cassava (DRC) for broilers.

\begin{tabular}{|c|c|c|c|c|c|c|c|}
\hline \multicolumn{8}{|c|}{ Chemical composition $\left(\mathrm{g} \mathrm{kg}^{-1}\right)$} \\
\hline Crude protein & & & & & 11.2 & & \\
\hline Ethereal extract & & & & & 3.1 & & \\
\hline Crude energy $\left(\mathrm{kcal} \mathrm{g}^{-1}\right)$ & & & & & 3.6 & & \\
\hline Mineral matter & & & & & 15.3 & & \\
\hline Neutral Detergent Fiber & & & & & 382.2 & & \\
\hline Acid Detergent Fiber & & & & & 208.2 & & \\
\hline Starch & & & & & 607.3 & & \\
\hline Crude fiber & & & & & 135.7 & & \\
\hline \multicolumn{8}{|c|}{ Energetic values of DRC inclusion levels (\%) (11-21d old) } \\
\hline & 10 & 20 & 30 & 40 & Mean & EPM & $p$ value \\
\hline AME kcal kg-1 & 1534 & 1529 & 1531 & 1527 & 1530 & 20.6 & 1.00 \\
\hline $\mathrm{AME}_{\mathrm{n}} \mathrm{kcal} \mathrm{kg}^{-1}$ & 1499 & 1480 & 1527 & 1535 & 1510 & 19.7 & 0.78 \\
\hline AMC \% & 42.6 & 42.5 & 42.5 & 42.4 & 42.5 & 0.6 & 1.00 \\
\hline $\mathrm{AMC}_{\mathrm{n}} \%$ & 41.6 & 41.1 & 42.4 & 42.6 & 41.9 & 0.6 & 0.78 \\
\hline \multicolumn{8}{|c|}{ Energetic values of DRC inclusion levels (\%) (31-41d old) } \\
\hline & 10 & 20 & 30 & 40 & Mean & EPM & $p$ value \\
\hline AME kcal kg-1 & 1749 & 1753 & 1753 & 1798 & 1763 & 26.7 & 0.94 \\
\hline $\mathrm{AME}_{\mathrm{n}} \mathrm{kcal} \mathrm{kg}^{-1}$ & 1712 & 1717 & 1734 & 1793 & 1739 & 28.9 & 0.78 \\
\hline AMC \% & 48.4 & 48.5 & 48.5 & 49.8 & 48.8 & 0.8 & 0.94 \\
\hline $\mathrm{AMC}_{n} \%$ & 47.4 & 47.5 & 48.0 & 49.6 & 48.1 & 0.8 & 0.78 \\
\hline
\end{tabular}

AME: apparent metabolizable energy; $\mathrm{AME}_{\mathrm{n}}$ : AME corrected for nitrogen balance; $\mathrm{AMC}$ : apparent metabolizable coefficient; $\mathrm{AMC}_{\mathrm{n}}$ : $\mathrm{AMC}$ corrected for nitrogen balance.

Table 4 - Performance of broiler chickens fed different levels of dry residue of cassava (DRC).

\begin{tabular}{|c|c|c|c|c|c|c|c|c|c|}
\hline \multirow[b]{2}{*}{ DRC (\%) } & \multicolumn{3}{|c|}{$1-7 d$ of age } & \multicolumn{3}{|c|}{$1-21 d$ of age } & \multicolumn{3}{|c|}{$1-42 d$ of age } \\
\hline & $\begin{array}{l}W^{1}{ }^{1} \\
(\mathrm{~g})\end{array}$ & $\begin{array}{l}\mathrm{FI} \\
(\mathrm{g})\end{array}$ & $\begin{array}{l}\mathrm{FCR}^{2} \\
\left(\mathrm{~g} \mathrm{~g}^{-1}\right)\end{array}$ & $\begin{array}{l}W G^{3} \\
(\mathrm{~g})\end{array}$ & $\begin{array}{c}\mathrm{FI} \\
(\mathrm{g})\end{array}$ & $\begin{array}{l}\mathrm{FCR}^{4} \\
\left(\mathrm{~g} \mathrm{~g}^{-1}\right)\end{array}$ & $\begin{array}{l}W^{5}{ }^{5} \\
(\mathrm{~g})\end{array}$ & $\begin{array}{c}\mathrm{FI} \\
(\mathrm{g})\end{array}$ & $\begin{array}{c}\mathrm{FCR}^{6} \\
\left(\mathrm{~g} \mathrm{~g}^{-1}\right)\end{array}$ \\
\hline 0.0 & 111 & 133 & 1.199 & 763 & 1142 & 1.497 & 2332 & 3970 & 1.702 \\
\hline 2.0 & 110 & 130 & 1.183 & 774 & 1157 & 1.496 & 2303 & 3962 & 1.720 \\
\hline 4.0 & 106 & 129 & 1.210 & 741 & 1149 & 1.551 & $2252^{*}$ & 3874 & 1.720 \\
\hline 6.0 & 106 & 133 & 1.260 & 741 & 1160 & 1.566 & 2251 * & 3910 & 1.737 \\
\hline 8.0 & $100 *$ & $124^{*}$ & 1.235 & 721 * & 1125 & 1.561 & $2163^{*}$ & 3830 & 1.771 * \\
\hline 10.0 & $100^{*}$ & $120 *$ & 1.203 & $717^{*}$ & 1160 & 1.580 & $2106^{*}$ & 3928 & $1.865^{*}$ \\
\hline 12.0 & $104^{*}$ & $121 *$ & 1.166 & $714^{*}$ & 1134 & $1.590 *$ & 2091 * & 3935 & $1.866^{*}$ \\
\hline CV (\%) & 5.45 & 5.62 & 4.81 & 4.36 & 3.74 & 4.30 & 4.78 & 2.72 & 4.13 \\
\hline SEM & 0.820 & 1.020 & 0.008 & 4.604 & 6.182 & 0.010 & 15.116 & 15.232 & 0.011 \\
\hline$p$ (Anova) & $<0.001$ & $<0.001$ & 0.060 & $<0.001$ & 0.670 & 0.023 & $<0.001$ & 0.163 & $<0.001$ \\
\hline$p$ (Linear) & 0.003 & 0.762 & 0.012 & 0.066 & 0.705 & 0.071 & 0.040 & 0.022 & 0.924 \\
\hline p (Quadratic) & 0.096 & 0.229 & 0.001 & 0.718 & 0.581 & 0.431 & 0.528 & 0.035 & 0.003 \\
\hline
\end{tabular}

${ }^{\prime} W G=112,1044218-1,811352 X ; R 2=0,40 ; 2 F C R 07=1,179275939+0,018503042 X-0,001592586 X 2 ; R 2=0,15(R D C=5,809 \% ; C A 07=1,308) ; 3 W G 21=770,7978965$ $-6,1842598 X ; R 2=0,40 ; ; 4 F C R 21=1,490177674+0,013944232 X ; R 2=0,26 ; 5 W G 42=2335,386001-16,710086 X ; R 2=0,68 ; 6 F C R 42=1,704973617-0,000498419 X+$ $0,001293739 X 2 ; R 2=0,87 ;$; ${ }^{*}$ Differs control by Dunnet's test at $5 \%$ probability; WG: weight gain; Fl: feed intake; FCR: feed conversion ratio.

while the inclusion of $8.0,10.0$ and $12.0 \%$ of DRC reduced the broilers' intake compared to birds that received the basal diet. The FCR showed a quadratic effect from 1-42 d of age ( $p=0.003)$ with a better FCR obtained by the inclusion of $0.19 \%$ DRC. The FCR from days $1-7$ had a tendency $(p=0.060)$ with quadratic effect $(p=0.001)$, and the worst FCR was observed with the inclusion of $5.81 \%$ of DRC. Inclusion above $5.81 \%$ may improve conversion.

Carcass $(p=0.011)$ and breast $(p=0.009)$ yields showed a decreasing linear effect, i.e., increasing the inclusion of DRC resulted in a linear decrease in carcass and breast yields (Table 5). Although there was a significant impact on relative liver weight $(p=0.019)$, it was not possible to adjust an adequate response to a linear $(p=0.261)$ or quadratic $(p=0.420)$ equation. For carcass yield, only 2.0 and $6.0 \%$ DRC inclusion levels did not differ $(p>0.05)$ from diets without DRC inclusion. The use of $10.0 \%$ of DRC resulted in a lower breast yield compared to control treatment, and 8.0\% of DRC provided a heavier liver compared to control birds. The use of fibrous feeds provided a reduction in abdominal fat content, but in this study, no difference was found $(p=0.196)$. Carcass FDR $\left(g\right.$ day $\left.^{-1}\right)$ had no 
Table 5 - Carcass and yields cuts, protein deposition rate (PDR), and fat deposition rate (FDR), intestinal morphology of broilers chickens fed different levels of dry residue of cassava (DRC).

\begin{tabular}{lccccccccccc}
\hline DRC (\%) & $\begin{array}{c}\text { Carcass }^{1} \\
\left(\mathrm{~g} \mathrm{~kg}^{-1}\right)\end{array}$ & $\begin{array}{c}\text { Breast } \\
\left(\mathrm{g} \mathrm{kg}^{-1}\right)\end{array}$ & $\begin{array}{c}\text { Legs } \\
\left(\mathrm{g} \mathrm{kg}^{-1}\right)\end{array}$ & $\begin{array}{c}\text { Wings } \\
\left(\mathrm{g} \mathrm{kg}^{-1}\right)\end{array}$ & $\begin{array}{c}\text { Abd. Fat } \\
\left(\mathrm{g} \mathrm{kg}^{-1}\right)\end{array}$ & $\begin{array}{c}\text { Liver } \\
\left(\mathrm{g} \mathrm{kg}^{-1}\right)\end{array}$ & $\begin{array}{c}\text { PDR } \\
\left(\mathrm{g} \mathrm{dia}^{-1}\right)\end{array}$ & $\begin{array}{c}\text { FDR } \\
\left(\mathrm{g} \mathrm{dia}^{-1}\right)\end{array}$ & $\begin{array}{c}\text { Villus } \\
(\mu \mathrm{m})\end{array}$ & $\begin{array}{c}\text { Crypta } \\
(\mu \mathrm{m})\end{array}$ & \begin{tabular}{c} 
Villus:Crypta \\
\hline 0.0
\end{tabular} \\
\hline 72.86 & 37.30 & 27.34 & 10.54 & 1.94 & 2.52 & 20.29 & 10.11 & 1024 & 190 & 5.40 \\
4.0 & 71.50 & 37.40 & 27.90 & 10.70 & 1.97 & 2.69 & 19.83 & 10.62 & 1000 & 188 & 5.32 \\
\hline 6.0 & $69.20^{*}$ & 34.70 & 28.13 & 11.10 & 1.94 & 2.87 & $16.15^{*}$ & 8.66 & 1000 & 194 & 5.17 \\
8.0 & 71.90 & 35.50 & 29.10 & 11.20 & 1.69 & 2.44 & 19.83 & 9.79 & 961 & 197 & 4.96 \\
10.0 & $69.80^{*}$ & 34.90 & 28.60 & 11.50 & 1.64 & $2.88^{*}$ & $17.27^{*}$ & 9.36 & 1016 & 201 & 5.08 \\
12.0 & $69.80^{*}$ & $33.40^{*}$ & 28.20 & 11.50 & 1.88 & 2.74 & $16.63^{*}$ & 9.05 & 1011 & 209 & 4.86 \\
\hline CV (\%) & $70.30^{*}$ & 35.40 & 29.00 & 11.30 & 1.02 & 2.73 & $16.32^{*}$ & 10.42 & 1028 & 214 & 4.80 \\
\hline SEM & 2.64 & 6.21 & 4.57 & 6.34 & 43.32 & 10.47 & 13.77 & 17.71 & 10.49 & 10.25 & 12.60 \\
$p$ (Anova) & 0.267 & 0.315 & 0.187 & 0.102 & 0.107 & 0.040 & 0.355 & 0.246 & 15.070 & 2.918 & 0.092 \\
$p$ (Linear) & 0.001 & 0.003 & 0.128 & 0.063 & 0.196 & 0.019 & $<0.001$ & 0.285 & 0.936 & 0.150 & 0.538 \\
$p$ (Quadratic) & 0.068 & 0.074 & 0.239 & 0.125 & 0.267 & 0.420 & 0.652 & 0.118 & 0.318 & 0.485 & 0.850 \\
\hline
\end{tabular}

${ }^{1}$ Carcass $=72,53764893-0,57617384 X ; R^{2}=0,22 ;{ }^{2}$ Breast $=37,71490877-0,68350793 X ; R^{2}=0,25 ;{ }^{*}$ Differs from control treatment by the Dunnett's Test at $5 \%$ probability.

significant effect $(p=0.285)$, while a significant effect was observed on PDR $(p<0.001)$ (Table 5); however, there was no adequate adjustment for linear $(p=0.132)$ or quadratic $(p=0.652)$ effects. Results of intestinal morphometry were not influenced $(p>0.05)$ by the inclusion of DRC (Table 5).

\section{DISCUSSION}

DRC has a high starch and fiber concentration, similar to the values observed by Abrahão et al. (2006) and Khempaka etal. (2009). The low EE and CP contents are an indication that its primary energy source comes from carbohydrates present in its composition. CF and ADF concentrations are high; these provide high levels of cellulose, lignin, lignified protein, and silica. The CF value of DRC is $784 \%$ and $279 \%$ higher than those found in corn and soybean meal, respectively. For ADF concentrations, these values are $659 \%$ and $268 \%$ higher than those of corn and bran soybeans, respectively, according to Rostagno et al. (2017). The effect of diet composition on energy metabolisabilitiy was reported previously, the low ether extract levels and the high concentration of fibrous compounds, which can affect starch digestibility, lead to low energy utilization by the birds (Al-Harthi et al., 2018).

The DRC did not influence the energetic values $\left(A M E\right.$ and $A M E_{n}$ ) or their respective metabolizable coefficients $A M C$ and $A M C_{n}$. However, a higher energy utilization $\left( \pm 200 \mathrm{kcal} \mathrm{kg}^{-1}\right.$ ) values were determined for birds over $31 \mathrm{~d}$ of age. Young birds aged 11 to $21 \mathrm{~d}$ have an incomplete digestive system that is still developing and maturing and concomitantly has low enzymatic activity, involving mainly amylase and lipase enzymes (Brumano et al., 2006; Mello et al., 2009;
Attia et al., 2020), providing a reduction in starch and fat digestibility. DRC has NSPs in its structure, which can decrease the efficiency of diet utilization, negatively affecting nutrient digestibility and consequently reducing daily WG (Brufau et al., 1994).

The more unsatisfactory performance of birds from days 1-7 may be related to the physiology of the gastrointestinal tract in birds, where specialized cells for digestion and absorption are only fully developed two to three weeks after hatching (Moran Jr., 1989). Birds do not have some of the endogenous enzymes needed for fiber digestion, such as xylanases, cellulases, and glucanases, which hydrolyze some fibrous compounds. The viscosity of the gastrointestinal environment makes it difficult for enzymes and intestinal substrates to reach the proteins, fats, and starch, and impairs nutrient digestion and absorption, thereby compromising the birds' performance (Brito et al., 2008).

The high fiber content and soluble NSPs in the diet can increase the digestion viscosity when in contact with water, forming gums, which increase the size of the bolus and consequently cause gastric distension, which in turn causes a feeling of satiety in the birds, reducing FI (Oliveira et al., 2012; Al-Harthi et al., 2020). The chemical composition of DRC shows that the cassava byproduct has a high starch content and a high fiber concentration, as also observed by Abrahão et al. (2006) and Khempaka et al. (2009), justifying the reduction in performance.

In addition to the high fiber content in DRC, one of the factors that may affect poor performance is the concentration of resistant starch that may have been formed by gelatinization and crystallization of amylose and amylopectin during the processing of the material. Starch digestion takes place mainly in the 
Trautenmüller H, Broch J, Pires Filho IC,

Silva IM, Frank R, Schöne RA,

Carvalho PLO, Eyng C, Nunes RV
Energetic Values and Inclusion Levels of the Dry

Residue of Cassava in Broiler Diet small intestine, forming glucose, but if it reaches the large intestine intact, fermentation and the release of short-chain fatty acids produced by microorganisms will occur (Noblet et al., 1994).

In addition to the nutritional composition of the residue, the amount of oil added to the rations, which despite increasing digestibility (Furlan \& Macari, 2002), contains lipids that stimulate the secretion of the intestinal hormone cholecystokinin (CCK) in the poultry duodenum, inhibiting gastric peristalsis and reducing $\mathrm{Fl}$ and passage rate.

According to Khempaka et al. (2009) using dried manioc pulp at 4.0, 8.0, 12.0 and $16.0 \%$ inclusions for broiler chickens from 1-42 d of age, with $13.59 \%$ CF and starch content of $53.55 \%$, resulting in a decrease in WG as well as increased inclusion and a reduction in abdominal fat. According to the authors, the loss in abdominal fat may be related to the inhibition of lipid synthesis in the liver and abdominal tissue due to the high raw fiber content of the feed used.

According to Promthong et al. (2004), birds fed diets containing cassava show increased liver size, which may result from the higher digestibility of cassava starch compared to corn, promoting increased glucose intake for hepatic blood glucose regulation and deposition as glycogen, resulting in increased liver weight.

The results of intestinal morphometry were not influenced by the inclusion of DRC. The crypt can be considered a villus factory, and a greater crypt depth indicates rapid tissue turnover and high demand for new tissue (Yason et al., 1987). Greater crypt depth may mean an increased rate of villus tissue replacement; this rapid replacement of enterocytes requires energy and protein, which may slow the growth and development of other tissues and organs (Markovic et al., 2009). However, high-fiber diets have an abrasive action on the intestinal epithelium, which may increase the rate of cell renewal that occurs in the crypts and thus increase their depth (Dierick et al., 1989). Jin et al. (1994) reported that fibrous feeds included in diets reduce villus height and increase crypt depth due to the abrasive action of the fiber and may alter the crypt depth/villus height ratio.

Increased crypt depth may indicate high cell proliferative activity, which usually occurs as a response of the intestinal epithelium to some mucosal injury and has the function of renewing villus height loss (Furlan et al., 2004). In the present study, villus height did not show significant differences between treatments, so it can be considered that the fiber present in the DRC did not negatively affect the cellular intestinal epithelial cell turnover rate, maintaining the similarity to the birds of the control treatment.

Carcass FDR ( day $^{-1}$ ) showed no significant effect, but lower PDRs were observed with the inclusion of $4.0,8.0,10.0$, and $12.0 \%$ of DRC, which may be related to lower WG and to worsen FCR from 1-42 d of age, demonstrating that the birds were not efficient in depositing protein in the carcass when the DRC inclusion increased.

\section{CONCLUSION}

Inclusion of DRC negatively affects performance; up to $6 \%$ inclusion was similar to the control treatment. The highest value found for breast yield was at the $8.66 \%$ inclusion level. Crypt depth increased linearly as a function of inclusion levels, and PDR decreased linearly with DRC inclusion.

\section{REFERENCES}

Abrahão JJS, Prado IN, Marques JA, Perotto D, Lugão SMB. Avaliação da substituição do milho pelo resíduo seco da extração da fécula de mandioca sobre o desempenho de novilhas mestiças em confinamento. Revista Brasileira de Zootecnia 2006;35(2):512-518.

Al-Harthi MA, Attia YA, Al-Sagan AA, Elgandy MF. Nutrients profile, protein quality and energy value of whole prosopis pods meal as a feedstuff for poultry feeding. Italian Journal of Animal Science 2018;18(1):30-38.

Al-Harthi MA, Attia YA, El-Shafey AS, Elgandy MF. Impact of phytase on improving the utilisation of pelleted broiler diets containing olive byproducts. Italian Journal of Animal Science 2020;19(1):310-318.

Almeida J, Ferreira Filho JR. Mandioca: uma boa alternativa para alimentação animal. Bahia Agrícola 2005;7(1):50-56.

AOAC - Association of Official Analytical Chemists. Official methods of analysis. $17^{\text {th }}$ ed. Arlington; 2000.

Araujo WAG, Albino LFT, Rostagno HS, Gomes PC, Pessoa GBS, Messias RKG, et al. Sunflower meal and enzyme supplementation in diets of broilers from 21 to 42 days of age. Iranian Journal of Applied Animal Science 2013;3(4):695-702.

Attia YA, Al-Harthi MA, El-Maaty HMA. The Effects of different oil sources on performance, digestive enzymes, carcass traits, biochemical, immunological, antioxidant, and morphometric responses of broiler chicks. Frontiers in Veterinary Science 2020;7:181.

Brito MS, Oliveira CFS, Silva TRG, Lima RB, Morais SB, Silva JHV. Polissacarídeos não amiláceos na nutrição de monogástricos-revisão. Acta Veterinaria Brasilica 2008;2(4):111-117.

Broch J, Nunes RV, Oliveira V, Silva IM, Souza C, Wachholz L. Dry residue of cassava as a supplementation in broiler feed with or without addition of carbohydrases. Semina: Ciências Agrárias 2017;38(4):2641-2658.

Carrijo AS, Fascina VB, Souza KMRD, Ribeiro SDS, Allaman IB, Garcia $A M L$, et al. Níveis de farelo da raiz integral de mandioca em dietas para fêmeas de frangos caipiras. Revista Brasileira de Saúde e Produção Anima 2010;11(1):131-139. 
Trautenmüller H, Broch J, Pires Filho IC,

Silva IM, Frank R, Schöne RA,

Carvalho PLO, Eyng C, Nunes RV
Energetic Values and Inclusion Levels of the Dry Residue of Cassava in Broiler Diet
Conte AJ, Teixeira AS, Fialho ET, Schoulten NA, Bertechini AG. Efeito da fitase e xilanase sobre o desempenho e as características ósseas de frangos de corte alimentados com dietas contendo farelo de arroz. Revista Brasileira de Zootecnia 2003;32(5):1147-1156.

Dierick NA, Vervaeke IJ, Demeyer DI, Decuypere JA. Approach to the energetic importance of fibre digestion in pigs. I. Importance of fermentation in the overall energy supply. Animal Feed Science and Technology 1989;23(1-3):141-167.

Fraga AL, Moreira I, Furlan AC, Bastos AO, Oliveira RPD, Murakami AE. Lysine requirement of starting barrows from two genetic groups fed on low crude protein diets.Brazilian Archives of Biology and Technology 2008;51(1):49-56.

Furlan RL, Macari M. Motilidade gastrointestinal. In: Macari M, Furlan, RL, Gonzales E. Fisiologia aviária aplicada a frangos de corte. $2^{\text {nd }}$ ed. Jaboticabal: FUNEP; 2002.

Furlan RL, Macari M, Luquetti BC. Como avaliar os efeitos do uso de prebióticos, probióticos e flora de exclusão competitiva. In: Anais do $5^{\circ}$ Simpósio Técnico de Incubação, Matrizes de Corte e Nutrição; 2004 Out 4-6; Balneário Camboriu, Santa Catarina. Florianópolis: ACAV; 2004. p. 6-28.

Jin L, Reynolds LP, Redmer DA, Caton JS, Crenshaw JDL. Effects of dietary fiber on intestinal growth, and morphology in growing pigs. Journal Animal Science 1993;72:2270-2278.

Khempaka S, Molee W, Guillaume M. Dried cassava pulp as an alternative feedstuff for broilers:Effect on growth performance, carcass traits, digestive organs, and nutrient digestibility. The Journal of Applied Poultry Research 2009;18(3):487-493.

Luna LG. Manual of the histologic staining methods of the armed forces institute of pathology. $3^{\text {rd }}$ ed. New York: McGraw Hill; 1968.

MAPA - Ministério da Agricultura, Pecuária e Abastecimento. Bem-estar animal no Brasil. Brasília, DF, 14 mar. 2016. Available from: http:// www.agricultura.gov.br/arq_editor/file/Aniamal/Bemestar-animal/ folder\%20BEA\%20versao\%202012\%20-\%2009_05_2013.pdf.

Markovi R, Sefer D, Krsti M, Petrujki B. Effect of different growth promoters on broiler performance and gut morphology. Archivos Medicina Veterinaria 2009;41:163-169.

Moghaddam HN, Salari S, Arshami JAVD, Golian A, Maleki M. Evaluation of the nutritional value of sunflower meal and its effect on performance, digestive enzyme activity, organ weight, and histological alterations of the intestinal villi of broiler chickens. Journal Applied Poultry Research 2012;21:293-304
Moran Jr. ET. Fat feeding value: relationships between analyses, digestion, and absorption. In: Proceedings of the Western Nutrition Conference; 1989; Saskatoon. Canadá; 1989. p.31-40.

Morgan NK, Choct M. Cassava: nutrient composition and nutritive value in poultry diets. Animal Nutrition 2016;2(4):253-261.

Nikam MG, Reddy VR, Raju MVLN. Effect of dietary supplementation of Non Starch Polysaccharide hydrolyzing enzymes on broilers reared on CornSoya standard and basal diets. International Journal of Agricultural Science and Research 23016;6(3):389-396.

Noblet J, Fortune H, Shi XS, Dubois S. Prediction of net energy value of feeds for growing pigs. Journal Animal Science 1994;72:344-354

Oliveira DD, Pinheiro JW, Fonseca NAN, Oba A. Desempenho de frangos de corte alimentados com torta de girassol. Semina: Ciências Agrárias 2012;33:1979-1990.

Picoli KP, Murakami AE, Nunes RV, Amaral DCR, Eyng C, Ospina RIC. Cassava starch factory residues in the diet of slow-growing broilers. Tropical Animal Health and Production 2014;46(8):1371-1381.

Rostagno HS, Albino LFT, Donzele JL, Gomes PC, Oliveira RF, Lopes DC, et al. Tabelas brasileiras para aves e suínos: composição de alimentos e exigências nutricionais. Viçosa: Universidade Federal de Viçosa; 2011. $186 \mathrm{p}$

Sakomura NK, Rostagno HS. Métodos de pesquisa em nutrição de monogástricos. Jaboticabal: Funep; 2007. 283 p.

SAS Institute. Installation guide for Windows. Cary; 2014.

Silva $D$, Queiroz AD. Análise de alimentos: métodos químicos e biológicos. $3^{\text {rd }}$ ed. Viçosa: UFV; 2004

Silva IM, Broch J, Wachholz L, De Souza C, Dalolio FS, Teixeira LV, et al. Dry residue of cassava associated with carbohydrases in diets for broiler chickens. Journal Applied Poultry Reserch 2019;28(4):1189-1201.

Silva MC, Siqueira JC, Vaz RGMV, Rodrigues KF, Albino LFT, Sousa F, et al. Replacement of soybean meal by babassu pie in balanced rations for broilers from one to 21 days of age. Semina: Ciências Agrárias 2015:36(6):3947-3956

Van Soest PJ, Robertson JB, Lewis BA. Methods for dietary fiber, neutral detergent fiber, and non-starch polysaccharides in relation to animal nutrition. Journal Dairy Science 1991;74:3583-3597.

Yason CV, Summers BA, Schat KA. Pathogenesis of rotavirus infection in various age groups of chickens and turkeys: pathology. American Journal of Veterinary Research 1987;48(6):927-938. 